\title{
Community Knowledge and Behavior in the Utilization of Medicinal Plants in Cikoneng Village Bandung District
}

\author{
Santun Bhekti Rahimah, ${ }^{1}$ Yuktiana Kharisma, ${ }^{1}$ Eka Nurhayati, ${ }^{2}$ Yuniarti, ${ }^{3}$ \\ Shenny Dianathasari Santoso, ${ }^{3}$ Muhammad Faridza ${ }^{4}$ \\ ${ }^{1}$ Department of Pharmacology, ${ }^{2}$ Department of Public Health, ${ }^{3}$ Department of Anatomy, \\ ${ }^{4}$ Medical Undergraduate Study Program, Faculty of Medicine, Universitas Islam Bandung, Bandung, Indonesia
}

\begin{abstract}
The industry of the traditional medicinal made from medicinal plants was currently growing. Effortless cultivation and utilization of medicinal plants were an important step to preserve the traditional medicine of Indonesia. Cikoneng village had abundant natural potential and is an assisted village of the researchers' institution located at the foot of Manglayang mountain Bandung district. Therefore, the researchers implemented the intervention program to educate and socialize the use of medicinal plants to the community of Cikoneng village. After the intervention program, the assessment of the level of knowledge and perceptions of people in the behavior of treatment by medicinal plants utilized was carried out. This study aims to assess the increase in knowledge and perceptions of people in the behavior of cultivation and treatment by using medicinal plants in Cikoneng village. The study used an intervention program and questionnaire with 35 respondents conducted on 22 August-23 September 2016. The results showed that after the intervention program, the level of knowledge of the Cikoneng village community regarding medicinal plants was right. The entire people of Cikoneng village is willing to take advantage of medicinal plants in maintaining family health and will begin to cultivate them in the smallest scope (family). In conclusion, there is an increase in people's knowledge and perception of the behavior of cultivation and treatment by utilizing medicinal plants in Cikoneng village.
\end{abstract}

Key words: Behavioral, Cikoneng village, community, herbal medicine, knowledge, perception

\section{Pengetahuan dan Perilaku Masyarakat dalam Pemanfaatan Tanaman Obat di Kampung Cikoneng Kabupaten Bandung}

\begin{abstract}
Abstrak
Industri obat tradisional berbahan baku tanaman obat saat ini semakin berkembang. Upaya budidaya dan pemanfaatan tanaman obat yang optimal merupakan langkah penting untuk menjaga kelestarian obat tradisional Indonesia. Kampung Cikoneng mempunyai potensi alam yang melimpah dan merupakan desa binaan institusi peneliti yang terletak di kaki Gunung Manglayang Kabupaten Bandung. Oleh karena itu, peneliti melaksanakan program intervensi untuk mengedukasi dan menyosialisasikan pemanfaatan tanaman obat kepada masyarakat Kampung Cikoneng. Pada akhir program intervensi, dilakukan penilaian tingkat pengetahuan dan persepsi masyarakat tentang perilaku pengobatan dengan tanaman obat. Penelitian ini bertujuan menilai peningkatan pengetahuan dan persepsi masyarakat tentang perilaku budidaya dan pengobatan dengan memanfaatkan tanaman obat di Kampung Cikoneng. Penelitian menggunakan program intervensi dan kuesioner dengan jumlah responden 35 orang yang dilaksanakan pada 22 Agustus-23 September 2016. Hasil memperlihatkan bahwa setelah program intervensi, tingkat pengetahuan masyarakat Kampung Cikoneng mengenai tanaman obat adalah baik. Seluruh masyarakat Kampung Cikoneng bersedia memanfaatkan tanaman obat dalam menjaga kesehatan keluarga dan akan mulai membudidayakannya dalam lingkup yang paling kecil (keluarga). Simpulan, terdapat peningkatan pengetahuan dan persepsi masyarakat tentang perilaku pengobatan dengan memanfaatkan tanaman obat di Kampung Cikoneng.
\end{abstract}

Kata kunci: Kampung Cikoneng, masyarakat, pengetahuan, perilaku, persepsi, tanaman obat

Received: 20 November 2017; Revised: 12 December 2018; Accepted: 14 December 2018; Published: 30 April 2019

Correspondence: Santun Bhekti Rahimah, dr., M.Kes. Department of Pharmacology, Faculty of Medicine, Universitas Islam Bandung. Jln. Tamansari No. 22, Bandung 40116, West Java, Indonesia. Mobile: +6282182180089. E-mail: santunbr94@gmail.com 


\section{Introduction}

Indonesia has many sources of plants and natural ingredients which use as medicinal plants. The use of medicinal plants started for thousands of years ago, but its utilization has not been optimal. Often raw materials from Indonesia cannot be used in their own country, so these raw materials exported abroad and after being commercialized by outside parties are then returned to Indonesia. Indonesian medicinal plants should be able to host their own country. ${ }^{1,2}$

The current government has promoted various programs related to efforts to improve the health of the community through the use of medicinal plants, including the program of family medicinal plants/tanaman obat keluarga (TOGA) and scientific certification of herbs..$^{3-5}$ Family medicinal plants are a program for the community related to the utilization of yield crops home-based cultivation that is efficacious as a medicine. This program is beneficial and efficient because in its implementation because it requires less extensive land, such as in the yard, garden or fields that can be used to cultivate plants that are efficacious as medicine in order to meet the family's need for medicines.

At present, the government is also promoting the use of traditional medicines in health through herbal medicine certification. The government wants the use of herbal medicine in the community to increase with the support of authorized health personnel. The use of traditional medicine itself used as a preventive, curative and complementary effort with modern medicine. ${ }^{3-5}$ Empowerment of medicinal plants in the community is not only a government program, but also requires the support of educational institutions, drug companies and the community itself to support success the program. The use of medicinal plants in the community needs to be revived for various aspects so that the results will be optimal.

The researchers' institution has several built regions/villages, one of which is Cikoneng village (Cibiru Wetan village, Cibiru Wetan subdistrict, Bandung district). The village enormous agricultural potential with geographical conditions and a very supportive climate. The area of Cikoneng village located at the foot of Manglayang mountain, which is mostly in the form of highlands (hills), while a small portion is in the form of lowlands and dominated by rice fields. The area is suitable for farming because in addition to fertile land, climate and elevation, and abundant water availability.

Based on the description above, the researcher will play an active role in helping the people of Cikoneng village to improve their health status, through increasing their knowledge of the community regarding the use of medicinal plants. This service activity is expected to provide insight into the importance of medicinal plants, how to use them and equip them with the necessary skills in making herbal plants. The use of this medicinal plant use as a preventive, curative, and rehabilitative effort in improving the health status of the family. Following the government program as well, in addition to the utilization of medicinal plants, the community is expected to increase knowledge about medicinal plant and perception level in seeking behavioral level to the utilization of herbal medicine at the Cikoneng village community.

\section{Methods}

This intervention program for the education of the community, involving the assisted villagers. The target of the intervention program is the residents of Cikoneng village, Cibiru Wetan sub-district, Bandung district, West Java province. This location chose because Cikoneng village is one of the village areas fostered by the researchers' institution. Its location, which is relatively far from the center of government and the city center, makes the majority of its residents prefer daily activities as laborers, farmers, farm laborers, farmers around their homes.

The inclusion criteria stipulated in this program are as follows residents of Cikoneng village, consists of farmers/farm laborers, integrated service center/pos pelayanan terpadu (posyandu) and family welfare education/ pendidikan kesejahteraan keluarga (PKK) members as activators of the program to use medicinal plants, and are willing to participate in this activity.

This program is a continuous and directed activity involving residents, posyandu cadres in Cikoneng village, and the Bandung District Agriculture Office. This program is planned to be carried out in three stages of activity or three periods of activity. The first period is education and program socialization, the second period is land use/planting postharvest medicinal plants and the third period are an establishment of Rumah Jamu Kampung (RUJAK) Cikoneng and establishment of Komunitas Pintar Obat Herbal 
(KOMPOR) Cikoneng.

The first period of the intervention program was held in the period 22 August to 23 September 2016, which divided into two stages of activity, the preparation and implementation stages. The preparation phase includes the activities of survey to analyze the situation and prepare for the implementation of activities. Support from the government and local authorities must also be fostered from the start because it is one of the factors that will determine the success of the program.

Educational materials provided to the community consisted of Module 1: Community empowerment in utilizing and cultivating herbal plants and Module 2: Practices in making simple herbal preparation and cultivation of medicinal plants.

At Module 1, the material provided is the introduction of traditional medicine, the role of medicinal plants in improving health status, and the introduction of types of medicinal plants that have been widely used empirically and based on scientific research. This module also contains ways to grow medicinal plants ginger, turmeric, and temulawak. This type of plants chosen because its efficacy was proven empirically and scientifically, its availability is easy, economical, and its cultivation is not difficult..$^{6-10}$

Module 2 contains the practice of making simple herbal preparations and cultivation of medicinal plant ginger, turmeric, and temulawak. Herbs preparations introduced to the public are the method of making infusions, decoctions, and herbal tea. The cultivation of medicinal plants is carried out on a micro scale, which is planting in a field of around. ${ }^{6-10}$

The final stage of the intervention program, knowledge and awareness of the community or residents regarding the cultivation of medicinal plants and their utilization will be assessed using a questionnaire, to see how the results of the socialization and program implementation. The questionnaire consisted of 30 item questions, divided become 15 items for assessing knowledge level and 15 items for assessing perception level in seeking behavior-every question consisting of one correct answer and two distractors. Assessments were graded o for the wrong answer and 5 for correct, and complete assessments graded into three categories. Good categories (value $>30$ ), adequate/enough ratings (grades $15-30)$ and poor ratings $(<15)$.

Devotion to the Cikoneng village community is carried out based on the planned design so that the final goal is achieved. The indicators were used to assess the success of the implementation of this program are the knowledge and perception level in seeking behavioral to the utilization of herbal medicine at the community of Cikoneng village Bandung regency.

This intervention program approved by the Health Research Ethics Committee of Faculty of Medicine, Universitas Islam Bandung by ethics approval letter number: 375/Komite Etik.FK/ IX/2016.

\section{Results}

At the end of the intervention program, the questionnaire regarding the medicinal plants and their use was carried out. The number of participants who were willing to fill out the questionnaire were 35 people with the characteristics as shown in Table 1.

Assessment of the level of knowledge of the community before the training was conducted qualitatively with discussion followed by question and answer session (Table 2).

\section{Discussion}

Herbal medicine is currently increasingly being used in the community as one of the primary treatment alternatives to improve health. ${ }^{1,5}$ The national health system shows data that household access that can provide health service facilities in remote areas is still low and expensive health services lead to low public accessibility to health services. This reinforces the need for the existence of this program to increase public knowledge about herbal medicine as an alternative treatment, so it is expected that the number of people seeking self-treatment will increase. ${ }^{11-13}$

Evaluation at the end of the intervention program, the questionnaire was taken regarding participants characteristics and knowledge about medicinal plants and their use. This study shows that most participants are female because they had more free time than male. Most of the male in Cikoneng village are farmers or gardeners. From Table 1, what is quite concerning is the education data and family income per month. Public education, in general, is still low, although for the younger generation it has begun to step on further education. Only one person has a diploma in education. Family income is still relatively low, 
Table 1 Participants Characteristics

\begin{tabular}{|c|c|c|}
\hline \multirow{2}{*}{ Characteristics } & \multicolumn{2}{|c|}{ Participants } \\
\hline & Male & Female \\
\hline \multicolumn{3}{|l|}{ Age (year) } \\
\hline$\leq 17$ & - & 4 \\
\hline $18-50$ & 5 & - \\
\hline$>50$ & - & 26 \\
\hline \multicolumn{3}{|l|}{ Status } \\
\hline Married & 5 & 4 \\
\hline No married & - & 26 \\
\hline \multicolumn{3}{|l|}{ Occupations } \\
\hline Housewife & - & 20 \\
\hline Laborer & 1 & - \\
\hline Farmer/gardener & 4 & 5 \\
\hline Pre-elementary teacher & - & 1 \\
\hline Unemployment & - & 4 \\
\hline \multicolumn{3}{|l|}{ Last education } \\
\hline No school & 1 & - \\
\hline Primary school & 2 & 12 \\
\hline Secondary school & 2 & 11 \\
\hline Senior high school (SHS) & - & 5 \\
\hline Unfinished SHS & - & 1 \\
\hline Diploma & - & 1 \\
\hline University & - & - \\
\hline \multicolumn{3}{|l|}{ Number of children } \\
\hline o & - & 5 \\
\hline 1 & 2 & 10 \\
\hline 2 & 1 & 8 \\
\hline 3 & 1 & 4 \\
\hline$>3$ & 1 & 3 \\
\hline \multicolumn{3}{|l|}{ Monthly income } \\
\hline No income & - & 4 \\
\hline$\leq$ Rp200,000.00 & - & 5 \\
\hline Rp200,000.00-Rp1,000,000.00 & 4 & 18 \\
\hline$\geq \mathrm{Rp} 1,000,000.00$ & 1 & 3 \\
\hline Blank data & - & - \\
\hline
\end{tabular}

with a large number of family members causing income to become increasingly inappropriate. Economic problems still seem to be one of the problems in this village, even though the location of this village is not too far from urban areas. Many opportunities can be developed in this village, including one that seeks the use of surrounding land for cultivation of herbs. The cultivation of herbal plants is expected to be a good enough commodity to improve the economic conditions

Table 2 Knowledge and Perception Levels in the Utilization and Cultivation of Medicinal Plants in the Cikoneng Village

\begin{tabular}{lccc}
\hline \multirow{2}{*}{ Parameters Assessed } & \multicolumn{3}{c}{ Category (\%) } \\
\cline { 2 - 4 } & Good & Enough & Poor \\
\hline Knowledge level & 80 & 20 & 0 \\
$\begin{array}{l}\text { Perception level in seeking behavioral } \\
\text { to utilization of herbal medicine }\end{array}$ & 100 & 0 & 0 \\
\hline
\end{tabular}


of the people in Cikoneng village. ${ }^{10,11}$

The questionnaire to participants looked at the level of community knowledge about herbal medicine before and after training and looked at their perceptions about the future use of medicinal plants or their treatment behavior in using medicinal plants. Questionnaire filling before training is complicated because the time is limited and conditions on the ground are not possible. ${ }^{12-14}$

Assessment of the level of knowledge of the community before the training was conducted qualitatively with discussion and question and answer with the participants present. The results illustrate that in general, they have heard about medicinal plants and their efficacy for health, but only superficially. They do not know much about the advantages and disadvantages of using medicinal plants in maintaining health, what are the types of medicinal plants and how they used. After training the level of community knowledge about medicinal plants, the efficacy and how to use medicinal plants is relatively increasing.

This study showed that after training the community has a right level of knowledge (80\%) and perception level in seeking behavioral the utilization of herbal medicine (100\%). The results are outstanding when compared with the Hilal and Hilal ${ }^{14}$ study, which shows data that the level of knowledge of herbal medicines of the participating physicians (64.6\%). In contrast, there were only two out of 96 participants (2.1\%) having an advanced level of knowledge of herbal medicines. Other studies that assessed the level of knowledge about herbal medicine for students in Bahrain showed that more than 50\% of respondents believed that herbal medicines were effective and should be integrated into the modern health care system. ${ }^{15}$ The research by Kashani et al. ${ }^{16}$ showed that $47.3 \%$ of participants from infertility patient in care center were knowledgeable of herbal remedies, with female gender and lower educational background being the associated factors in knowledge.

The healthy behavior of the community is very closely related to the comprehensive patient handling cycle, which starts from preventive, curative, rehabilitative and promotive. In each phase, the community is expected to have good behavior so that eventually it will improve health. When a person faced with a sick or unhealthy condition, some people look for modern medicine that is closely related to chemical drugs, while others seek traditional medicine such as using herbal medicines. The community must understand the concept of traditional medicine with medicinal plants (herbal medicine) correctly. In principle, medicinal plants allow it to develop so that the types and herbal preparations available can vary, and their use is optimal..$^{4-10}$

Good knowledge shall increase individual attitudes to be more positive about using herbal medicines. Study of Hilal and Hilal, ${ }^{14}$ it was seen that almost all physicians in participants had never used herbal medicines. Research in Bahrain showed about $70 \%$ of the students surveyed had used at least one form of herbal therapy. ${ }^{15}$ Another study in Kenya involving 167 patients at a herbal clinic in the Gucha district showed that $68.9 \%$ preferred using herbal medicines. ${ }^{17}$ In this study, participants showed a desire to use herbal medicine as much as $100 \%$. These results prove that the program intervention carried out has given participants good experience and knowledge about medicinal plants.

\section{Conclusion}

There is an increase in people's knowledge and perception of the behavior of cultivation and treatment by utilizing medicinal plants in Cikoneng village.

\section{Conflict of Interest}

All authors have not conflict of interest in publishing this article.

\section{Acknowledgements}

Researchers would like to thank the Faculty of Medicine, Universitas Islam Bandung and parties from local Agriculture Service and the support of village officials who have helped implement this intervention program.

\section{References}

1. World Health Organization (WHO). Legal status of traditional medicine and complementary/alternative medicine: a worldwide review. 2001 [cited 2015 March 9]. Available from: https://apps.who.int/ medicinedocs/pdf/h2943e/h2943e.pdf.

2. Hamda SS, Khanuja SPS, Longo G, Rakesh DD. Extraction technologies for medicinal and aromatic plants. Trieste, Italy: United Nations Industrial Development 
Organization (UNIDO) and the International Centre for Science and High Technology (ICS); 2008.

3. Dinas Kesehatan Kota Bandung. Tindak lanjut penyelenggaraan pengembangan model peningkatan kesehatan kawasan kumuh miskin Tamansari Kota Bandung. Bandung: Dinas Kesehatan Kota Bandung; 2013.

4. Subdit Bina Kesehatan Perkotaan dan Olahraga, Direktorat Bina Kesehatan Kerja dan Olahraga, Kementerian Kesehatan Republik Indonesia. Konsep model penyelenggaraan peningkatan kesehatan di kawasan kumis perkotaan. Jakarta: Kementerian Kesehatan Republik Indonesia; 2013.

5. Siswanto. Saintifikasi jamu sebagai upaya terobosan untuk mendapatkan bukti ilmiah tentang manfaat dan keamanan jamu. Bul Penel Sistem Kes. 2012;15(2):2013-11.

6. Dewi M, Aries M, Hardiansyah, Dwiriani CM, Januwati M. Pengetahuan tentang manfaat kesehatan temulawak (Curcuma xanthorrhiza) serta uji klinis pengaruhnya pada sistem imun humoral pada dewasa obes. JIPI. 2012;17(3):166-71.

7. Tim Tropical Plants Curriculum(TPC) Project. Modul tanaman obat herba berakar rimpang. Bogor: Southeast Asian Food \& Agricultural Science \& Technology (SEAFAST) Center; 2012 [cited 2017 June 18]. Available from: https://docplayer.info/40112407-Tanamanobat-herba-berakar-rimpang.html.

8. Balai Besar Penelitian dan Pengembangan Pascapanen Pertanian, Kementerian Pertanian Repubik Indonesia. Teknologi pascapanen tanaman obat. Bogor: Balai Besar Penelitian dan Pengembangan Pascapanen Pertanian, Kementerian Pertanian Repubik Indonesia; 2012 [cited 2017 June 18]. Available from: http://pascapanen.litbang. pertanian.go.id/assets/media/publikasi/ Tanaman_Obat_2101.pdf.

9. Purwanto DA, Poernomo AT, Annuryanti F. Pengembangan industri kreatif sirup jamu sehat untuk pemberdayaan posdaya di Kabupaten Sidoarjo. JLM. 2017;1(1):1-9.

10. Arifah FH, Pramono S, Nugroho AE. Efek rebusan rimpang segar, rebusan rimpang kering, minyak atsiri, dan kurkumin Curcuma xanthorrhiza Roxb. terhadap kadar bilirubin pada tikus jantan galur wistar yang diinduksi parasetamol. JTOI. 2018;11(2):8-16.

11. Peraturan Presiden Republik Indonesia Nomor 72 Tahun 2012 tentang Sistem Kesehatan Nasional.

12. Murni SA, Prawito P, Widiono S. Eksistensi pemanfaatan tanaman obat tradisional (TOT) suku Serawai di era medikalisasi kehidupan. Naturalis. 2012;1(3):225-34.

13. World Health Organization (WHO). Benchmarks for training in traditional/ complementary and alternative medicine: benchmarks for training in naturopathy. Geneva: WHO Press; 2010.

14. Hilal M, Hilal S. Knowledge, attitude, and utilization of herbal medicines by physicians in the Kingdom of Bahrain: a cross-sectional study. JAAUBAS. 2017;24:325-33.

15. Nworu CS, Udeogaranya PO, Okafor CK, Adikwu AO, Akah PA. Perception, usage and knowledge of herbal medicines by students and academic staff of University of Nigeria: a survey. Eur J Integr Med. 2015;7(3):218-27.

16. Kashani L, Hassanzadeh E, Mirzabeighi A, Akhondzadeh S. Knowledge, attitude and practice of herbal remedies in a group of infertile couples. Acta Med Iran. 2013;51(3):189-94.

17. Ondicho J, Ochora J, Matu E, Mutai J. Factors associated with use of herbal medicine among patients in herbal clinics in Gucha district, Kenya. JSCP. 2015;(1):74-87. 